\title{
Studies in Vivo and in Vitro on Chemically-Induced Primary Islet Cell Tumours and Non-tumour Endocrine Pancreatic Tissue
}

\author{
P. Masiello, C. B. Wollheim, B. Blondel and A. E. Renold \\ Institut de Biochimie Clinique, University of Geneva, Geneva, Switzerland
}

\begin{abstract}
Summary. Rat islet cell tumours induced by injection of streptozotocin and nicotinamide have been studied in vivo and after the establishment of monolayer cultures of tumour cells. During an intravenous glucose tolerance test, tumour-bearing rats had increased release of immunoreactive insulin, with a high proportion of proinsulin, as well as accelerated glucose disposal relative to control rats. The tumours were rich in immunoreactive insulin and somatostatin, poor in glucagon. Non-tumour pancreatic tissue or isolated islets contained $10 \%$ or less of the corresponding normal amounts of insulin whereas the islet content of somatostatin was unchanged and that of glucagon increased. This is best interpreted as a selective suppression of non-tumour B cells, further supported by the observation that the initially reduced insulin release and content
\end{abstract}

of non-tumour islets were partially restored after 2 days in tissue culture. In monolayer culture, tumour cells maintained insulin production and acute responsiveness to glucose for prolonged periods. There was no sign of cell proliferation. It is concluded that primary, chemically-induced insulin-producing pancreatic islet cell tumours retain several features characteristic of normal B cells and continue to influence glucose homeostasis in vivo.

Key words: Islet cell tumour, intravenous glucose tolerance, primary monolayer culture, isolated islets, insulin release, immunoreactive insulin, immunoreactive glucagon, immunoreactive somatostatin, streptozotocin.
Pancreatic islet cell tumours containing large amounts of immunoreactive insulin (IRI) can be induced in the rat by combined administration of streptozotocin and nicotinamide [1-3]. Previous studies in vivo, which tested glucose tolerance and insulin response of tumourbearing rats, did not give consistent results $[2,4,5]$. More recently, some reports have dealt with insulin release from these chemically-induced tumours in vitro either in a perifusion system [6] or in the isolated perfused tumour-bearing pancreas [7]. Because of the potential usefulness of these tumours either for biochemical investigations or as a model of chronic hyperinsulinism in vivo, a more detailed study of such tumours and the adaptive changes of the non-tumour endocrine pancreas appeared warranted. One of the aims of the present study was to examine further glucose-stimulated insulin release and the proportion of released proinsulin in vivo. The feasibility of growing tumour cells in monolayer cultures was also investigated, as well as the effect of glucose on insulin release from cultured cells. Since signs of suppression of the B cells in the non-tumour pancreatic tissue have been reported $[8,9]$, the changes of insulin content and release of islets isolated from the hypoglycaemic hyperinsulinaemic tumour-bearing rats, have been evaluated. Finally, the reversibility of the changes in islet function was tested in tissue culture.

\section{Materials and Methods}

\section{Induction of Tumours}

Approximately 100 Wistar rats of $160 \mathrm{~g}$ body weight received nicotinamide $(500 \mathrm{mg} / \mathrm{kg}) \mathrm{IP}$, followed after $15 \mathrm{~min}$ by an IV injection of streptozotocin $(60 \mathrm{mg} / \mathrm{kg})$, freshly dissolved in citrate buffer $(10 \mathrm{mmol} / 1, \mathrm{pH} 4.5)$. Control rats were injected with the same dose of nicotinamide followed by citrate buffer alone. Some of the treated rats died for unknown reasons during the first 2 months following the injection, whereas others were sacrificed at different intervals. After 16-18 months, the 32 surviving streptozotocin-injected animals and five control rats injected with nicotinamide alone were used for the present study.

\section{Intravenous Glucose Tolerance Test}

Fifteen hours after food withdrawal, 17 treated rats weighing $450-600 \mathrm{~g}$ and four control rats weighing $470-640 \mathrm{~g}$, were anaesthetized with sodium pentobarbital $(50 \mathrm{mg} / \mathrm{kg}, \mathrm{IP})$ and given $1.5 \mathrm{~g} / \mathrm{kg}$ glucose ( $40 \%$ solution) via a jugular venous catheter. Blood samples were collected in heparinized tubes at $0,5,10,20,30,45,60,75$ and $90 \mathrm{~min}$ after the glucose injection. Plasma was stored at $-20^{\circ} \mathrm{C}$ until assayed. 


\section{Column Chromatography of Insulin and Proinsulin}

Plasma samples or aliquots of tumour extracts were applied to a column $(0.8 \times 70 \mathrm{~cm})$ of Sephadex G-50 (Pharmacia, Zurich, Switzerland) and eluted with glycine buffer $(0.2 \mathrm{~mol} / \mathrm{l})$ containing $0.25 \%$ bovine serum albumin (BSA), $\mathrm{pH} 8.8$, collecting $1 \mathrm{ml}$ fractions. The column was calibrated using Dextran blue, $\left.{ }^{125} \mathrm{I}\right]$-pork insulin and unlabelled beef proinsulin as markers.

\section{Isolation of Tumour Cells}

The intrapancreatic tumour nodules were removed under aseptic conditions, cut into small pieces as free as possible from capsular tissue and washed in phosphate buffered saline solution. Tumour cells were isolated by a modification of the method used by Meda et al. for adult pancreatic islets [10]. The finely cut tumour pieces were incubated for $20 \mathrm{~min}$ at $37^{\circ} \mathrm{C}$ in a $\mathrm{Ca}^{++}$-free Krebs-Ringer bicarbonate (KRB) buffer containing glucose $(16.7 \mathrm{mmol} / 1), 0.5 \%$ BSA and EDTA ( $3 \mathrm{mmol} / \mathrm{l})$. At the end of this preliminary incubation, the tumour pieces were collected after centrifugation and resuspended for repeated incubation for $5-10 \mathrm{~min}$ at $37^{\circ} \mathrm{C}$ in $\mathrm{Ca}^{++}$free-KRB buffer, without EDTA, but with glucose $(16.7 \mathrm{mmol} / \mathrm{l}), 0.1 \% \mathrm{BSA}$ and $0.1 \%$ tryp$\sin$ (Difco, Detroit, USA, $1: 250$ ), until only fibrous tissue remained. The single cells or cell clumps obtained by this procedure were washed several times with fresh culture medium, counted and plated in plastic Petri dishes, $3.5 \mathrm{~cm}$ in diameter (Falcon Plastics, Oxnard, CA, USA). The medium was Dulbecco's modified Eagle's medium (DMEM) containing 10\% fetal calf serum, penicillin $(400 \mathrm{IU} / \mathrm{ml})$, streptomycin $(200 \mu \mathrm{g} / \mathrm{ml})$ and glucose $(8.3 \mathrm{mmol} / 1)$. Plating density was $3-5 \times 10^{5}$ cells per dish ( $2 \mathrm{ml}$ medium).

\section{Maintenance and Incubation of Cultures of Tumour Cells}

Unless otherwise stated, the culture medium was not changed during the first week of culture in order to facilitate the attachment of the endocrine cells. Thereafter, cultures were maintained for weeks or months with medium changes every 3-4 days. Release of IRI, glucagon (IRG) and somatostatin was measured throughout, whereas short-term incubation experiments were performed on cultures plated 1-4 weeks previously. In the latter instance, Petri dishes containing clusters of tumour cells, were washed and then incubated for $1 \mathrm{~h} \mathrm{in}$ DMEM $(2 \mathrm{ml})$ with $10 \%$ fetal calf serum and glucose $(2.8 \mathrm{mmol} / \mathrm{l})$. At the end of the incubation, $1 \mathrm{ml}$ of the medium was withdrawn from each dish for IRI measurements and another $\mathrm{ml}$ of medium containing glucose to yield a final concentration of $16.7 \mathrm{mmol} / 1$ was added. After a further hour of incubation at the higher glucose concentration, IRI was again measured in the medium.

\section{Isolation, Incubation and Culture of Non-tumour Islets}

Islets were isolated from the pancreas after removal of all visible tumour nodules, using a modification of the collagenase technique of Lacy and Kostianovsky [11]. The hormone content of these islets (see below) was determined before and after 2 days of culture in DMEM containing glucose $(8.3 \mathrm{mmol} / \mathrm{l})$. In three separate experiments, isolated islets from tumour-bearing rats were incubated in the presence of different concentrations of glucose both before and after culture, using sterile conditions and plastic multi-well plates with $1.7 \times 1.6 \mathrm{~cm}$ wells (Linbro, Irvine, Scotland, UK). In particular, three to four islets per well were incubated for $30 \mathrm{~min}$ in modified KRB buffer $(0.5 \mathrm{ml})$ containing $\mathrm{NaHCO}_{3}(5 \mathrm{mmol} / \mathrm{l}), 0.5 \%$ dialyzed BSA, N-2-hydroxyethylpiperazine- $\mathrm{N}^{\prime}$-2-ethanesulphonic acid (Hepes) $(10 \mathrm{mmol} / \mathrm{l}, \mathrm{pH}$ $7.4)$ and glucose $(2.8 \mathrm{mmol} / \mathrm{l})$. At the end of the incubation, $0.25 \mathrm{ml}$ buffer was withdrawn under microscopic control for insulin measurement and another $0.25 \mathrm{ml}$ buffer, made up to yield a final glucose concentration of $16.7 \mathrm{mmol} / 1$, was added to each well for a second $30 \mathrm{~min}$ incubation period. Thereafter, the buffer was removed and $1 \mathrm{ml}$ of DMEM with glucose $(8.3 \mathrm{mmol} / \mathrm{l})$ was added and the islets maintained in culture for 2 days. At this time culture medium was collect- ed, the cultured islets washed twice and again incubated twice for $30 \mathrm{~min}$ in KRB-Hepes buffer with glucose $(2.8$ and $16.7 \mathrm{mmol} / \mathrm{l}) \mathrm{se}-$ quentially, repeating the protocol followed before culture. At the end of the second $30 \mathrm{~min}$ incubation period, the islets were washed and extracted for determination of insulin content. All the buffer changes were carried out under a dissecting microscope, to avoid loss of islets.

\section{Hormone Extraction of Tumour, Pancreas and Islets}

Pancreatic hormones were extracted from tumour fragments $(1-2 \mathrm{mg})$, pieces of non-tumour pancreatic tissue and isolated islets by a modification of the Kenny technique [12], using ice-cold acidified ethanol $(0.7 \mathrm{~mol} / 1 \mathrm{HCl} /$ ethanol, $1: 3 \mathrm{v} / \mathrm{v})$. In some cases tumour fragments were extracted by sonication in glycine buffer $(0.2 \mathrm{~mol} / \mathrm{l})$ with $0.25 \%$ BSA ( $\mathrm{pH} 8.8$ ). Both methods yielded similar results. Pieces of the whole pancreas were sonicated twice on two consecutive days in the acid-ethanol mixture, the resulting supernatants were pooled and used for the insulin determinations.

\section{Assays}

Plasma glucose was assayed with glucose-oxidase [13]. Insulin, glucagon and somatostatin were measured by radioimmunoassay according to Herbert et al. [14], using rat insulin, pork glucagon and cyclic somatostatin as standards [15].

The sensitivity and the variations of the radioimmunoassays were as follows: for insulin, detection limit $60 \mathrm{pg} / \mathrm{ml}$, intra-assay variation $2.4 \%$, inter-assay variation $7.0 \%$; for glucagon, detection limit $38 \mathrm{pg} /$ $\mathrm{ml}$, intra-assay variation $1.8 \%$, inter-assay variation $8.9 \%$; for somatostatin, detection limit $9.2 \mathrm{pg} / \mathrm{ml}$, intra-assay variation $2.0 \%$, inter-assay $10.7 \%$.

\section{Insulin Biosynthesis}

Tumour pieces (1-2 mg) were incubated in $0.5 \mathrm{ml}$ Eagle's minimal essential medium without leucine, containing glucose $(4-5 \mathrm{mmol} / \mathrm{l})$, $0.5 \% \mathrm{BSA}$ and $80 \mu \mathrm{Ci}\left[4,5-{ }^{3} \mathrm{H}\right]$ leucine (specific activity $55 \mathrm{Ci} / \mathrm{mmol}$ ). After $3 \mathrm{~h}$ of incubation at $37^{\circ} \mathrm{C}$, the tumour pieces were washed three times in KRB-Hepes buffer and then sonicated in $1 \mathrm{ml}$ glycine buffer $(0.2 \mathrm{mmol} / 1)$, with $0.25 \%$ BSA $(\mathrm{pH} 8.8)$. The sonicates were centrifuged at $30,000 \times g$ for $30 \mathrm{~min}$ in a Beckman high speed centrifuge (Model L5-65), and supernatants were used for analysis. The specifically immunoprecipitable radioactivity, as well as the total trichloroacetic acid-precipitable radioactivity, were measured as described by Halban et al. [16].

\section{Statistical Analysis}

Statistical analysis was performed using Student's t-test for unpaired or paired data where appropriate.

\section{Results}

Thirty-two animals were alive $16-18$ months after combined administration of nicotinamide and streptozotocin. Twenty-six of them (81\%) exhibited at least one nodule in the pancreas, while six had no visible tumour. The majority of the 26 tumour-bearing animals harboured more than one pancreatic nodule, two nodules being found in 11 and three to five nodules in six rats. The intrapancreatic tumour nodules were round, encapsulated and well vascularized, averaging some $0.5 \mathrm{~cm}$ in diameter and demonstrating occasional haemorrhagic spots. The distribution of the nodules within the pancreas was random. 
Table 1. Fasting plasma glucose and insulin concentrations of control and streptozotocin/nicotinamide-treated rats either with or without visible intrapancreatic tumours

\begin{tabular}{lll}
\hline & $\begin{array}{l}\text { Plasma glucose } \\
(\mathrm{mmol} / \mathrm{l})\end{array}$ & $\begin{array}{l}\text { Plasma immuno- } \\
\text { reactive } \\
\text { insulin } \\
(\mathrm{ng} / \mathrm{ml})\end{array}$ \\
\hline $\begin{array}{lll}\text { Control rats } & 6.5 \pm 1.6(4) & 0.66 \pm 0.13(4) \\
\text { Tumour-bearing rats } & 2.5 \pm 0.2(22)^{\mathrm{a}} & 1.33 \pm 0.14(19)^{\mathrm{b}} \\
\begin{array}{l}\text { Treated rats without visible } \\
\text { tumour }\end{array} & 3.7 \pm 0.6(4)^{\mathrm{c}} & 0.55 \pm 0.20(4)^{\mathrm{c}}\end{array}$ \\
\hline
\end{tabular}

Results are expressed as mean \pm SEM. The number of rats is indicated in parentheses. ${ }^{\mathrm{a}} p<0.001,{ }^{\mathrm{b}} p<0.05,{ }^{\mathrm{C}}$ not significant versus control rats. $1 \mathrm{ng}$ of rat insulin corresponds to $24 \mu \mathrm{U}$
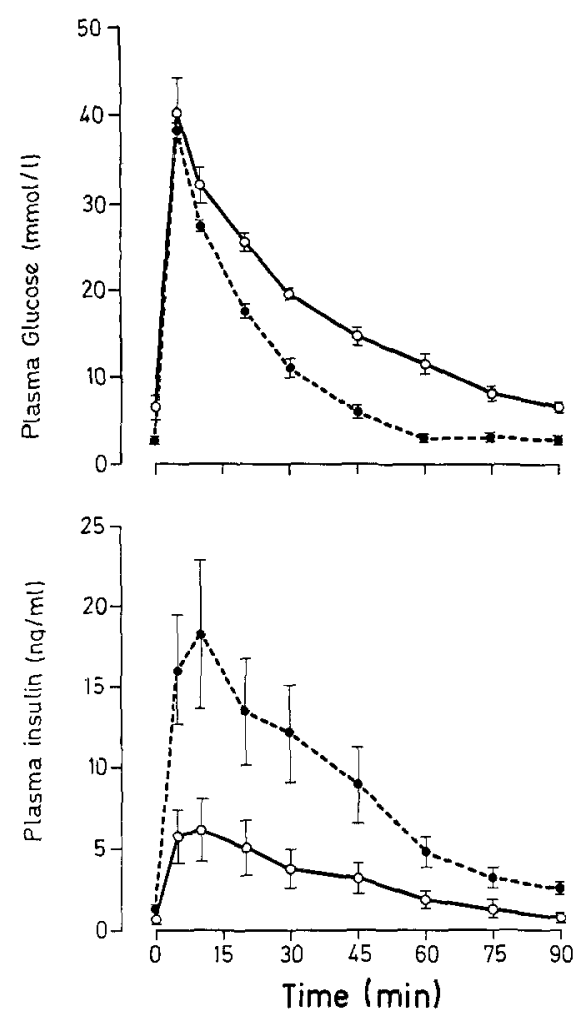

Fig. 1. Plasma glucose and immunoreactive insulin concentrations in response to IV glucose injection $(1.5 \mathrm{~g} / \mathrm{kg}$ body weight) in control $O-O(n=4)$, and tumour-bearing rats $-(n=17)$. Results are given as mean \pm SEM

\section{Experiments in Vivo}

Fasting plasma glucose levels were markedly lower in tumour-bearing rats than in controls (Table 1). The corresponding plasma IRI concentrations were twice those of control rats. Whether the observation that treated rats without visible tumour had intermediate glycaemia and normal insulinaemia (Table 1), is real and reproducible remains to be seen. When glucose $(1.5 \mathrm{~g} / \mathrm{kg}$ body weight $)$ was administered IV to tumourbearing animals, its disappearance rate was clearly accelerated relative to that of controls (Fig. 1). Plasma IRI rose markedly after glucose injection in tumour-bearing animals, reaching a peak at $10 \mathrm{~min}$ and declining thereafter. Plasma insulin increment varied considerably from one animal to the next, although plasma glucose varied much less. In looking for possible reasons for such a discrepancy, the contribution of biologically less active proinsulin was also estimated in plasma samples containing high levels of IRI after glucose injection. With column chromatography, the percentage of insulin immunoreactivity found in the proinsulin region of the eluates varied widely (between 13 and $71 \%$, mean \pm SEM $42 \pm 8 \%, n=8$ ). In half of these eluates, the proinsulin area was larger than that of insulin and, in two instances, the proinsulin/insulin ratio, when followed sequentially, remained unchanged between 5 and $30 \mathrm{~min}$. In contrast to tumour-bearing rats, no proinsulin peak appeared in the eluates of plasma samples from control rats after IV glucose.

\section{Studies of Tumour Tissue in Vitro}

The tumours contained large amounts of IRI (mean \pm SEM $9.71 \pm 1.09 \mu \mathrm{g} / \mathrm{mg}$ wet weight, $n=23$ ), considerable amounts of somatostatin $(54.6 \pm 14.7 \mathrm{ng} / \mathrm{mg}, n=$ $16)$, but little or no measurable IRG $(0.81 \pm 0.37 \mathrm{ng} /$ $\mathrm{mg}, n=22$ ). Indeed, 13 of these 22 tumours had IRG levels below the limit of detection in acid-ethanol extracts (approximately $200 \mathrm{pg} / \mathrm{mg}$ tissue). There was no apparent correlation between the concentrations of the various hormones in the individual tumours. The percentage of proinsulin in the tumour extracts submitted to column chromatography was $6.2 \pm 1.3 \%$ of the total insulin immunoreactivity $(n=6)$.

Insulin was synthesized by tumour fragments incubated in vitro. Thus, during a $3-\mathrm{h}$ incubation of such fragments in the presence of $\left[4,5^{3} \mathrm{H}\right]$ leucine and glucose $(4.5 \mathrm{mmol} / \mathrm{l})$, the specifically immunoprecipitable radioactivity was $8.7 \pm 1.3 \%$ of the total radioactivity precipitable with trichloroacetic acid $(n=8)$. When the effects of glucose $(16.7 \mathrm{mmol} / \mathrm{l})$ on insulin biosynthesis and release were tested under these conditions, no consistent stimulation was observed. Because of the inconsistent results obtained with tumour pieces, it was considered important to find a more favourable system for the study of insulin secretion in vitro. To this end, primary monolayer cultures of tumour cells were established. These cultures had been maintained for weeks, sometimes months, with tumour cells usually attaching slowly after plating and forming clusters, but showing no evidence of replication. The expected concomitant growth of fibroblasts rarely overgrew the epithelioid cell clusters before 2 months. Electron microscopy of cells harvested 60 days after plating showed well-preserved fine structures with many typical B granules. D cells were also present, identified by the morphology of their granules. Release of IRI, IRG and somatostatin as a function of culture time is shown for such a primary culture in Figure 2. Here, as in a number of other exper- 


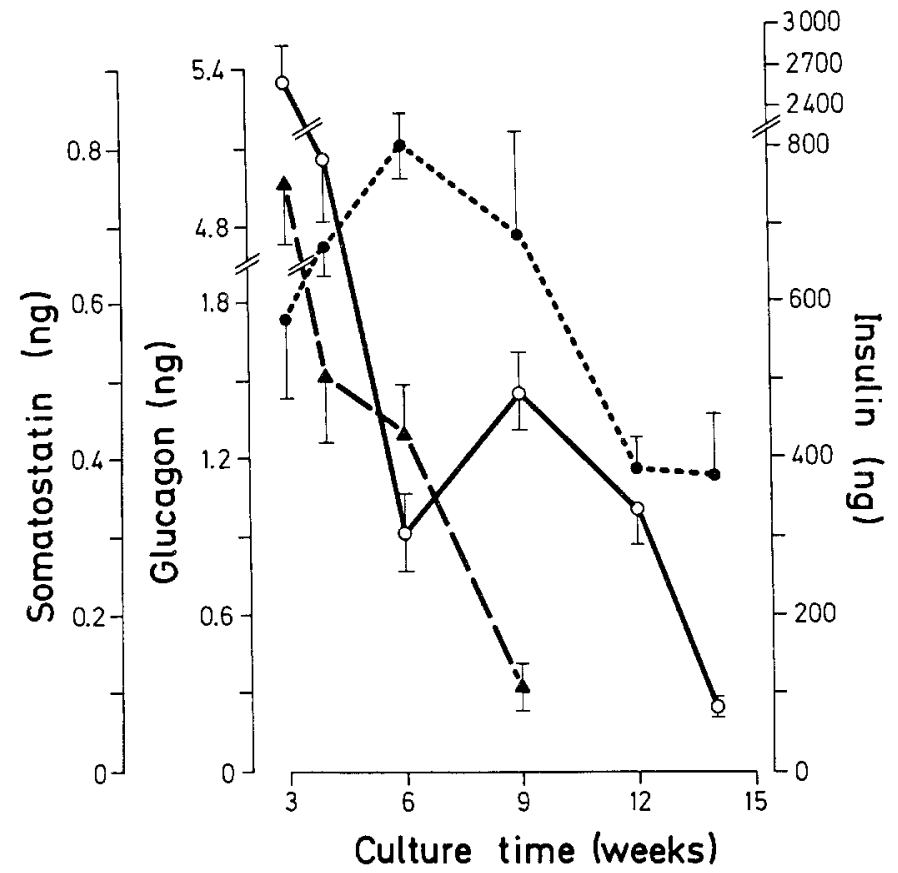

Fig. 2. Release of immunoreactive insulin $\mathrm{O}-\mathrm{O}$, glucagon $\Lambda$ and somatostatin -..-- from monolayer cultures of tumour cells as a function of culture time. Isolated cells were plated at a concentration of $5 \times 10^{5}$ cells per dish. The hormone measurements were carried out over a 24-h period after the addition of $2 \mathrm{ml}$ of fresh culture medium containing glucose $(8.3 \mathrm{mmol} / \mathrm{l})$. Results are given as mean \pm SEM of three to four observations. In one Petri dish insulin release was followed up to 6 months. At this time $7.8 \mathrm{ng}$ of insulin was still released over $24 \mathrm{~h}$

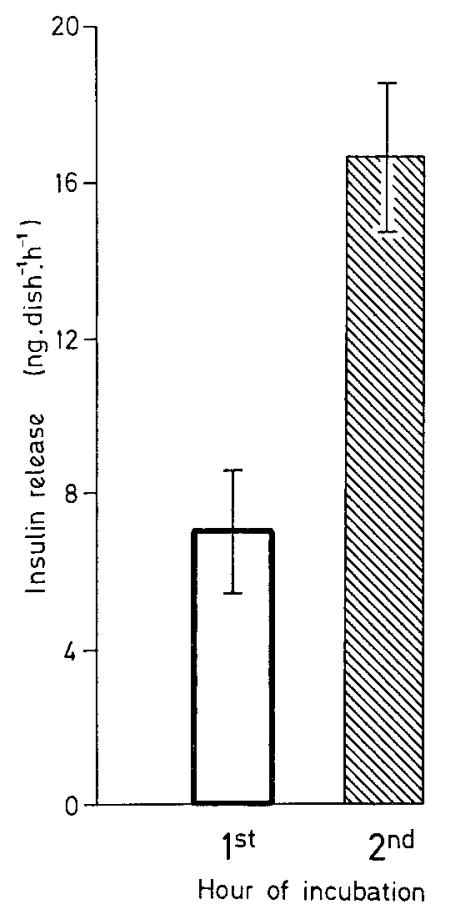

Fig.3. Effect of glucose on immunoreactive insulin release during short-term incubations of monolayer cultures of tumour cells. Two consecutive incubations of $1 \mathrm{~h}$ each were carried out in Dulbecco's modified Eagle's medium containing glucose at either $2.8 \mathrm{mmol} / \mathrm{l}(\square)$ or $16.7 \mathrm{mmol} / 1$ (\$). Experiments were performed 8-29 days after plating. Results are given as mean \pm SEM of 11 observations. The difference in insulin release was highly significant $(p<0.001)$ iments, IRI and somatostatin release were reasonably maintained for some $9-12$ weeks. The culture shown in Figure 2, however, was unusual in also maintaining significant IRG release for at least 6 weeks, reflecting perhaps the relatively high IRG content of the tumour $(2.53 \mathrm{ng} / \mathrm{mg})$ from which this culture was derived.

The results of short-term incubations (hours) performed on 11 separate cultures established from four different tumours plated between 8 and 29 days before the experiments, are shown in Figure 3. IRI release was more than doubled by raising the glucose concentrations from $2.8 \mathrm{mmol} / 1$ during the first hour of incubation to $16.7 \mathrm{mmol} / 1$ during the following hour. Two of these cultures ( 22 and 29 days after plating) were identically challenged again with glucose 2 weeks later. In both instances, however, they now failed to augment the rate of insulin release, when the glucose concentration was increased.

\section{Studies on Isolated Non-tumour Islets from the Pancreas of Tumour-Bearing Rats}

It can be calculated that the average tumour nodule (weight approximately $40 \mathrm{mg}$ ) contained about $400 \mu \mathrm{g}$ IRI, i. e. more than the content of the entire pancreas of age-matched controls; the latter averaged an insulin concentration of $277 \pm 43 \mathrm{ng} / \mathrm{mg}(n=5)$ or approximately $300 \mu \mathrm{g}$ per pancreas $(1 \mathrm{~g})$. Therefore, the IRI content of the non-tumour endocrine pancreas was measured and the responses of non-tumour islets of tumour-bearing animals were analyzed. The non-tumour pancreas contained $29.1 \pm 6.9 \mathrm{ng} \mathrm{IRI} / \mathrm{mg}(n=16)$, i. e. about $10 \%$ of the concentration in control animals.

When islets could be isolated from non-tumour pancreas of tumour-bearing rats, they were reduced in number, of comparable size, but often more translucent than control islets. The non-tumour islets were studied either immediately after isolation or after an intervening 2-day maintenance in tissue culture at glucose $(8.3 \mathrm{mmol} / \mathrm{l})$ and their hormone contents are shown in Table 2. IRI content of the freshly isolated islets from non-tumour pancreas of tumour-bearing animals was reduced to about $7 \%$ of that of control islets, but approximately tripled after 2 days of culture. By contrast, the islets isolated from rats treated with streptozotocin and nicotinamide but without visible pancreatic nodules, when freshly isolated, had $44 \%$ of the insulin content of islets from control rats. The IRI content of these islets exhibited a modest decrease (approximately 35\%) after culture, a decrease which corresponds to the usual response of islets from normal rats under the same culture conditions $[17,18]$. IRG and somatostatin contents of islets isolated from tumour-bearing pancreas were also measured before and after culture (Table 2). A significant IRG increase was observed in non-tumour islets isolated from tumour-bearing rats, when compared with freshly isolated islets of controls; IRG content, however, decreased after 2 days of culture in these islets 
Table 2. Hormone contents of islets isolated from pancreas of control rats, from non-tumour pancreas of tumour-bearing rats and from pancreas of rats without visible tumours. The two latter groups of islets, isolated from animals treated with streptozotocin and nicotinamide, were studied either freshly after isolation, or after a period of 2 days in tissue culture at glucose $(8.3 \mathrm{mmol} / \mathrm{l})$

\begin{tabular}{lccc}
\hline Islet donor rats & $\begin{array}{l}\text { Immunoreactive insulin } \\
\text { (ng/islet) }\end{array}$ & $\begin{array}{l}\text { Immunoreactive glucagon } \\
\text { (ng/islet) }\end{array}$ & $\begin{array}{l}\text { Immunoreactive somatostatin } \\
\text { (ng/islet) }\end{array}$ \\
\hline $\begin{array}{l}\text { Controls } \\
\text { Before culture }\end{array}$ & $74.7 \pm 3.4(44)$ & $2.85 \pm 0.20(43)$ & $0.36 \pm 0.04(46)$ \\
$\quad$ Tumour-bearing rats & & & $0.32 \pm 0.06(19)$ \\
$\quad$ Before culture & $4.9 \pm 1.0^{\mathrm{a}}(24)$ & $4.31 \pm 0.72^{\mathrm{a}}(14)$ & $0.37 \pm 0.04(32)$ \\
$\quad$ After culture (2 days) & $13.6 \pm 1.8^{\mathrm{b}}(41)$ & $2.29 \pm 0.27^{\mathrm{b}}(35)$ & \\
$\quad$ Treated rats without visible tumour & $34.6 \pm 3.5^{\mathrm{a}}(23)$ & $2.71 \pm 0.44(15)$ & $1.40 \pm 0.28^{\mathrm{c}}(11)$ \\
$\quad$ Before culture & $21.9 \pm 1.9^{\mathrm{c}}(12)$ & & \\
$\quad$ After culture (2 days) &
\end{tabular}

Results are expressed as mean \pm SEM. The number of determinations is indicated in parentheses.

${ }^{\mathrm{a}} p<0.01$ versus islets of control rats; ${ }^{\mathrm{b}} p<0.01$ versus islets before culture; ${ }^{\mathrm{c}} p<0.05$ versus islets before culture

Table 3. Insulin content and production of non-tumour islets isolated from tumour-bearing rats before and during a period of 2 days in tissue culture at glucose $(8.3 \mathrm{mmol} / \mathrm{l})$

\begin{tabular}{|c|c|c|c|c|}
\hline & \multicolumn{4}{|c|}{ Immunoreactive insulin (ng/islet) } \\
\hline Experiment 2 & $0.9 \pm 0.3(5)$ & $4.3 \pm 1.0$ & $1.7 \pm 0.3(10)$ & $5.2 \pm 1.3$ \\
\hline Experiment 3 & $12.3 \pm 2.0$ & $24.7 \pm 3.3(10)$ & $17.0 \pm 2.2(11)$ & $28.3 \pm 3.1(10)$ \\
\hline
\end{tabular}

Results are expressed as mean \pm SEM. The number of determinations is indicated in parentheses

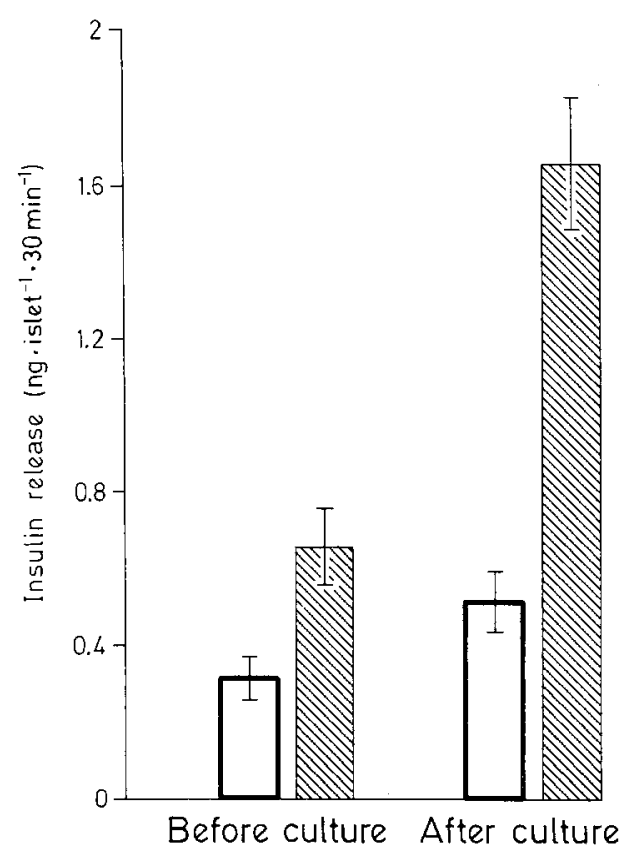

Fig.4. Glucose-stimulated insulin release from non-tumour pancreatic islets before and after 2 days of culture. Islets were isolated from the pancreas of tumour-bearing rats and incubated under sterile conditions for two consecutive $30 \mathrm{~min}$ periods in a modified Krebs-Ringer-bicarbonate buffer containing glucose at either $2.8 \mathrm{mmol} / \mathrm{I}(\square)$ or $16.7 \mathrm{mmol} / \mathrm{l}(\mathbb{\$})$. After 2 days of maintenance in culture medium at glucose $(8.3 \mathrm{mmol} / 1)$, the same islets were again incubated as before. Results are given as mean \pm SEM of 11 observations. The effect of glucose $(16.7 \mathrm{mmol} / \mathrm{l})$ was highly significant both before and after culture $(p<0.005)$ as well as in the islets isolated from treated rats without a visible tumour. The islets of tumour-bearing rats contained the same levels of somatostatin as control islets; somatostatin remained unaltered after culture.

IRI secretion and its regulation by glucose was also investigated in islets isolated from tumour-bearing rats, during incubation in KRB-Hepes buffer, both before and after 2 days in tissue culture. The incubation of freshly isolated islets was carried out under sterile conditions, so that it was possible to culture them for 2 days and then to incubate the same islets again. Three such experiments were performed with islets taken from three separate tumour-bearing animals. While the absolute values of IRI release varied because of differences in the initial islet insulin content (Table 3), there was considerable similarity between all three experiments. An addition to experiment 3 of Table 3 is shown in Figure 4 , in which the freshly isolated islets were exposed to glucose $(16.7 \mathrm{mmol} / 1)$ for $30 \mathrm{~min}$ immediately after an initial $30 \mathrm{~min}$ incubation at glucose $(2.8 \mathrm{mmol} / \mathrm{l})$. IRI release was increased approximately twofold both in absolute terms (Fig.4) and when expressed as percentage of the content measured in separate islets of the same batch. After 2 days of culture, the IRI content doubled (Table 3, experiment 3 ) and basal IRI release during the $30 \mathrm{~min}$ incubation was increased by $50 \%$. Glucose $(16.7 \mathrm{mmol} / \mathrm{l})$ now caused a threefold stimulation of IRI release relative to glucose $(2.8 \mathrm{mmol} / \mathrm{l})$. The same threefold stimulation results from expressing the 
IRI release as percentage of IRI content after the 2-day culture. For comparison, the IRI release of freshly isolated islets of control rats over a $30 \mathrm{~min}$ period was 1.05 $\pm 0.15 \mathrm{ng} /$ islet in the presence of glucose $(2.8 \mathrm{mmol} / 1)$, increasing to $5.56 \pm 0.65 \mathrm{ng} /$ islet in the presence of glucose $(16.7 \mathrm{mmol} / \mathrm{l})$.

Finally, the net IRI production (stored and released) during the 2-day culture period was estimated. The three experiments shown in Table 3 clearly demonstrate that the net production of IRI was 18,6 and 2.5 times the initial islet IRI content. The latter value, which refers to islets with a relatively high initial IRI, is quite similar to that observed when normal islets are maintained in tissue culture $[18,19]$. It thus becomes apparent that the non-tumour islets taken from tumour-bearing pancreas retain in part the ability to release insulin in response to glucose in vitro, despite their low insulin content. Such islets improve their functional capacity after 2 days of culture in the presence of physiological concentrations of glucose.

\section{Discussion}

The high yield of rat islet cell tumours obtained in this study after the combined administration of streptozotocin and nicotinamide confirms the reliability of this means for the induction of an otherwise very uncommon tumour [20].

Despite the high IRI content of the tumours, the rats exhibited only a moderate hyperinsulinaemia and hypoglycaemia in the fasted state. However, taking into account the reduction in the IRI content of non-tumour endocrine pancreatic tissue, the total insulin stored in tumour and pancreas was only augmented by $40-50 \%$ compared with normal animals. Furthermore, insulin secretion remains fairly well controlled since these tumours are not fatal, in contrast with another, more rapidly growing, rat insulinoma [21, 22].

The studies performed so far on the capability of rats with streptozotocin and nicotinamide-induced islet cell tumours to release IRI in response to glucose, have yielded variable results. Thus, in one study, an oral glucose load caused improved glucose tolerance with increased plasma insulin [4], while no change was found following IV glucose in another report [5]. Other authors, who measured blood glucose concentrations only during IV glucose tolerance tests, observed increased glucose disappearance in one sub-group and decreased disappearance in another sub-group of tumour-bearing rats [2].

The results of the IV glucose tolerance test reported here included determinations at early time points and established that tumour-bearing animals have accelerated glucose clearance rates compared with controls. No tumour-bearing animal provided evidence for decreased glucose disappearance rate. IRI release in re- sponse to glucose was markedly enhanced, albeit with a large scatter. In some animals, discrepancy between the conspicuous IRI release and only a moderately altered glucose clearance, suggested either the presence of inactive insulin-like molecules or the development of insulin resistance. The analysis of the molecular species of insulin immunoreactivity in plasma of eight tumourbearing rats after glucose administration established that proinsulin was always present, in contrast to control rats. Nevertheless, the correction of IRI levels for proinsulin, still did not afford correlation with glucose clearance rates, suggesting that insulin resistance may be involved.

The tumours contained large amounts of IRI and somatostatin, yet only small amounts of IRG. When comparing hormone contents in tumours and in normal rat islets, both expressed per mg wet weight, the tumour tissue contained $65 \%$ IRI, $55 \%$ somatostatin and $0.06 \%$ IRG, relative to normal islet tissue [23]. Therefore, in these tumours the normal relative proportions of IRI and somatostatin are maintained, while that of IRG is dramatically decreased. Similar to human insulinomas [24], the streptozotocin and nicotinamide-induced tumours have a proportionally larger secretion of proinsulin in plasma than would be expected from the tumour content.

Tumour cells were maintained in monolayer cultures for prolonged periods of time but failed to proliferate to any significant extent. Thus, as in vivo, these cells have limited growth potential and in culture behave more like normal B cells than transformed B cells $[25,26]$. The cultured tumour cells retained for about one month the capacity to increase insulin release when challenged with glucose. At later times, while insulin secretion into the culture medium continued, the sensitivity to glucose was lost. Recently, glucose-stimulated insulin release from tumour tissue in vitro has been shown for perifused tumour fragments [6], and for perfusion of tumour-containing pancreas [7].

Presence of this chemically-induced islet cell tumour has been reported to cause 'suppression' of the normal endocrine pancreas $[8,9]$. In line with these reports, a striking reduction of insulin content was observed in non-tumour pancreatic tissue and isolated islets. This reduction appears to be a selective phenomenon, since islet somatostatin content did not change and IRG content even increased. The change in islet IRG may be the result of hypoglycaemia-induced counterregulation. Despite the markedly reduced IRI content, freshly isolated islets from tumour-bearing rats retained responsiveness of IRI release to glucose, although diminished when compared to islets from control rats. This is in agreement with previous studies performed in Syrian hamsters bearing a transplantable insulinoma $[27,28]$. In a recent report concerning streptozotocin-induced insulinomas, the insulin secretion in response to glucose from freshly isolated islets was usually, but not always, found to be normal [6]. 
Both chronic hypoglycaemia and/or hyperinsulinaemia may be involved in the reduction of pancreatic insulin, but the main cause remains unclear. Whatever the reduction is due to, it is reversible, since the insulin content of isolated islets from tumour-bearing rats increased almost threefold after 2 days of culture in the presence of physiological concentrations of glucose. This increase did not occur in islets isolated from treated animals without visible tumours, which served as controls, since they had been subjected to the same initial treatment. Furthermore, the islets isolated from tumour-bearing rats increased not only net insulin production (Table 3), but also glucose-stimulated insulin release (Fig. 4), after tissue culture. The reversibility during culture of the islet changes and the fact that there is a clear indication of $B$ cell suppression in rats bearing streptozotocin-induced transplanted insulinomas [8], rule out the possibility that the observed changes in islet function could be the result of the primary insult caused to B cells by streptozotocin.

Since the islets of tumour-bearing rats are able to release insulin in response to glucose in vitro, the question arises whether the in vivo glucose-stimulated insulin release originates from the islets rather than from the tumours. This appears unlikely, as a reduction of the pancreatic insulin content similar to that observed in this study, should result in decreased glucose tolerance and insulin release [29]. Another indication of the secretory activity of the tumour is the high concentration of plasma proinsulin.

It is concluded that streptozotocin and nicotinamide-induced islet cell tumours synthesize, store and release insulin both in vivo and in vitro during prolonged cell culture. Therefore, these tumours may provide a relatively convenient source of B cells with sufficiently differentiated function for biochemical studies of the control mechanisms concerned. In addition, these tumour-bearing rats represent a model of slowdeveloping, long-lasting and moderate hyperinsulinism of pancreatic origin.

Acknowledgements. The expert animal care of Mr. C. Jorand, and the skillful technical assistance of Ms. J.Bassi, are gratefully acknowledged. Dr. P. Masiello was a recipient of a fellowship from the ItalianSwedish Foundation Stiftelsen Blanceflor Boncompagni-Ludovisi, Stockholm, Sweden.

\section{References}

1. Rakieten N, Gordon BS, Beaty A, Cooney DA, Davis RD, Schein PS (1971) Pancreatic islet cell tumors produced by the combined action of streptozotocin and nicotinamide. Proc Soc Exp Biol Med 137: 280-283

2. Dixit PK, Bauer GE (1976) Studies on rats with islet beta cell tumors induced by nicotinamide and streptozotocin. Proc Soc Exp Biol Med 152: 232-236

3. Kazumi T, Yoshino G, Fujii S, Baba S (1978) Tumorigenic action of streptozotocin on the pancreas and kidney in male Wistar rats. Cancer Res 38: 2144-2147
4. Kazumi T, Yoshino G, Yoshida Y, Doi K, Yoshida M, Kaneko S, Baba S (1978) Biochemical studies on rats with insulin-secreting islet cell tumors induced by streptozotocin: with special reference to physiological response to oral glucose load in the course of and after tumor induction. Endocrinology 103: 1541-1545

5. Creutzfeldt W, Arnold R, Creutzfeldt C, Frerichs H (1980) Induction of hormone-producing pancreatic tumours in the rat. In: Andreani D, Lefebvre PS, Marks V (eds) Current views on hypoglycaemia and glucagon. Academic Press, London, New York pp 205-221

6. Frigo I, Younoszai R, Dixit PK, Matta SG, Bauer GE (1981) Insulin release in vitro from islet tissues and adenomas of rats treated with nicotinamide and streptozotocin. The effects of glucose. Diabetes 30: 302-309

7. Kazumi T, Sakamoto C, Ohki A, Yoshino G, Otsuki M, Baba S (1981) Insulin release from the isolated perfused rat pancreas containing insulinomata induced by streptozotocin and nicotinamide: effects of glucose and responses to tumor removal. Endocrinology 109: $607-610$

8. Chick WL, Appel MC, Weir GC, Like AA, Lauris V, Porter JG, Chute RN (1980) Serially transplantable chemically induced rat islet cell tumors. Endocrinology 107: 954-960

9. Yoshino G, Utsumi M, Kazumi T, Makimura H, Ishihara K, Kobayashi N, Terashi K, Morita S, Baba S (1980) Pancreatic insulin, glucagon and somatostatin concentrations in rats with islet cell tumors induced by streptozotocin. Endocrinol Japon 27: 561-565

10. Meda P, Hooghe-Peters EL, Orci L (1980) Monolayer cultures of adult pancreatic islet cells on osmotically distupted fibroblasts. Diabetes 23: 497-500

11. Lacy PE, Kostianovsky M (1967) Method for the isolation of intact islets of Langerhans from the rat pancreas. Diabetes 16:35-39

12. Kenny J (1955) Extractable glucagon of the human pancreas. J Clin Endocr 15: 865-871

13. Bergmeyer HU, Bernt E (1970) Methoden der Enzymatischen Analyse. Verlag Chemie, Weinheim, p 1172

14. Herbert V, Lau K-S, Gottlieb CW, Bleicher SJ (1965) Coated charcoal immunoassay of insulin. J Clin Endocr 25: 1375-1384

15. Gerber PPG, Trimble ER, Wollheim CB, Renold AE, Miller RE (1981) Glucose and cyclic AMP as stimulators of somatostatin and insulin secretion from the isolated, perfused rat pancreas: a quantitative study. Diabetes 30:40-44

16. Halban PA, Wollheim CB, Blondel B, Renold AE (1980) Longterm exposure of isolated pancreatic islets to mannoheptulose: evidence for insulin degradation in the $\beta$-cell. Biochem Pharmacol 29: 2625-2633

17. Ribes G, Siegel EG, Wollheim CB, Renold AE, Sharp GWG (1981) Rapid changes in calcium content of rat pancreatic islets in response to glucose. Diabetes 30: 52-55

18. Rabinovitch A, Cuendet GS, Sharp GWG, Renold AE, Mintz DH (1978) Relation of insulin release to cyclic AMP content in rat pancreatic islets maintained in tissue culture. Diabetes 27: 766-773

19. Halban PA, Wollheim CB, Blondel B, Niesor E, Renold AE (1979) Perturbation of hormone storage and release induced by cyproheptadine in rat pancreatic islets in vitro. Endocrinology 104: 1096-1106

20. Schoental R (1975) Pancreatic islet-cell and other tumors in rats given heliotrine, a monoester pyrrolizidine alkaloid, and nicotinamide. Cancer Res 35: 2020-2024

21. Chick WL, Warren S, Chute RN, Like AA, Lauris V, Kitchen KC (1977) A transplantable insulinoma in the rat. Proc Natl Acad Sci USA 74: 628-632

22. Masiello P, Wollheim CB, Janjic D, Gjinovici A, Blondel B, Praz GA, Renold AE. Stimulation of insulin release by glucose in a transplantable rat islet cell tumor. Endocrinology (in press)

23. Trimble ER, Renold AE (1981) Ventral and dorsal areas of rat pancreas: islet hormone content and secretion. Am J Physiol 240: E422-E427

24. Creutzfeldt W, Arnold R, Creutzfeldt C, Deuticke U, Frerichs $H$, Track NS (1973) Biochemical and morphological investigations of 30 human insulinomas. Diabetologia 9: 217-231 
25. Niesor EJ, Wollheim CB, Mintz DH, Blondel B, Renold AE, Weil $R$ (1979) Establishment of rat pancreatic endocrine cell lines by infection with Simian virus 40. Biochem J 178: 559-568

26. Santerre RF, Cook RA, Crisel RMD, Sharp JD, Schmidt RJ, Williams DC, Wilson CP (1981) Insulin synthesis in a clonal cell line of Simian virus 40 -transformed hamster pancreatic beta cells. Proc Natl Acad Sci USA 78: 4339-4343

27. Sodoyez J-C, Sodoyez-Goffaux F, Lefebvre PJ, Foà PP (1968) A transplantable insulinoma of the Syrian hamster mesocricetus auratus auratus. Review of its properties and of its effects on the host. Acta Diabetol Lat 5 (Suppl 1): 86-104

28. Dunbar JC, Walsh MF, Foà PP (1976) Secretion of immunoreactive insulin and glucagon in hamsters bearing a transplantable insulinoma. Diabete Metab 2: 165-169
29. Junod A, Lambert AE, Stauffacher W, Renold AE (1969) Diabetogenic action of streptozotocin: relationship of dose to metabolic response. J Clin Invest 48: 2129-2139

Received: 30 December 1981

and in revised form: 9 July 1982

Dr. C. B. Wollheim

Institut de biochimie clinique

Sentier de la Roseraie

1211 Geneva 4

Switzerland 